NBER WORKING PAPER SERIES

\title{
THE DISTRIBUTIONAL EFFECTS \\ OF THE TAX TREATMENT \\ OF CHILD CARE EXPENSES
}

\author{
William M. Gentry \\ Alison P. Hagy
}

Working Paper No. 5088

\section{NATIONAL BUREAU OF ECONOMIC RESEARCH 1050 Massachusetts Avenue \\ Cambridge, MA 02138 April 1995}

We thank Rosanne Altshuler, David Bradford, Phil Cook, Charlie Clotfelter, Doug Holtz-Eakin, Jean Kimmel, Brigitte Madrian, Margie McElroy, Gib Metcalf, Jim Poterba and participants at the NBER Summer Institute and Tax Policy Analysis Conference for helpful comments. We remain responsible for any errors. This paper is part of NBER's research program in Public Economics. Any opinions expressed are those of the authors and not those of the National Bureau of Economic Research.

(C) 1995 by William M. Gentry and Alison P. Hagy. All rights reserved. Short sections of text, not to exceed two paragraphs, may be quoted without explicit permission provided that full credit, including $\odot$ notice, is given to the source. 


\title{
THE DISTRIBUTIONAL EFFECTS \\ OF THE TAX TREATMENT \\ OF CHILD CARE EXPENSES
}

\begin{abstract}
Tax relief for child care expenses, encompassing the Child Care Tax Credit and Dependent Care Assistance Plans, is the largest federal government program in the United States aimed at helping families with child care. We examine the distributional effects of these policies among families with children using both the National Child Care Survey and tax return data. Among families that use tax relief, the benefits average 1.24 percent of family income. Benefits as a percentage of income vary systematically over the income distribution. Despite being regressive at low income levels (mainly due to the credit being non-refundable), tax relief is progressively distributed over most of the income distribution with the ratio of benefits to income falling above the bottom quintile of the income distribution. The benefits of tax relief also vary among families with the same income depending on a family's structure and its labor market and child care choices.
\end{abstract}

William M. Gentry

Department of Economics

Duke University

Box 90097

Durham, NC 27708

and NBER

\author{
Alison P. Hagy \\ Department of Economics \\ Pomona College \\ Claremont, CA 91711
}




\section{The Distributional Effects of the Tax Treatment of Child Care Expenses}

The Child Care Tax Credit (CCTC) is the largest federal government program in the United States aimed at helping families with child care. ${ }^{1}$ In 1991 , over 5.9 million households took the CCTC costing the government $\$ 2.8$ billion in tax revenues (Internal Revenue Service, SOI Bulletin, Spring 1993). This paper measures the distributional effects of the CCTC and Dependent Care Assistance Plans (DCAPs), an alternative tax relief program administered as an employee benefit that allows families to pay for child care with pre-tax income.

The tax credit's critics claim that it is regressive since it benefits middle and upperincome families without offering relief to less-advantaged families. ${ }^{2}$ Yet, previous research by Dunbar and Nordhauser (1991) and Altshuler and Schwartz (1994) using tax return data shows that the tax credit is progressive. As with any government program targeted at child care, tax relief will redistribute resources from households without children to families with children. However, as discussed by Altshuler and Schwartz, much of this redistribution cancels out over the lifecycle: families with young children may receive tax relief now but will not receive relief when their children are older. Since this type of redistribution is transitory, we focus on measuring the redistribution of benefits within the population of families with children. This redistribution comes from the various tax rules pertaining to tax relief for child care, how child care expenditures vary with income, and differences in family choices regarding child care.

Our primary data source is the National Child Care Survey (NCCS); although, when possible, we compare our results with those obtained using a sample of tax returns. The

\footnotetext{
${ }^{1}$ For a review of the numerous government programs aimed at child care, see Robins (1990).

${ }^{2}$ See Garfinkel, Meyer and Wong (1990) for simulations of how various expansions of the CCTC would affect poverty and welfare recipiency.
} 
NCCS surveys families with at least one child under age 13 and thus isolates a cohort of families with children of eligible ages for tax relief. In addition, the NCCS includes information that is not available from the previously analyzed tax return data. For example, it has information on access and participation in DCAPs and details on family structure, labor force participation, and child care expenses. This information allows us to investigate what family characteristics affect whether a family receives tax relief and, if so, how much tax relief it receives. We can also construct an alternative ability-to-pay measure, potential labor income, based on wage and individual characteristic data. The advantage of this alternative measure of ability-to-pay is that it is related to a family's labor market opportunities rather than its preferences for leisure.

Our results suggest that a broad cross-section of Americans benefit from tax relief for child care. However, tax relief does not reach the bottom 10 percent of the income distribution primarily because the CCTC is nonrefundable. Despite this regressivity at low income levels, we find that above the bottom quintile of the income distribution tax relief is progressive: the effective subsidy rate (i.e., tax relief benefits divided by income) steadily declines with income. We attribute this progressivity to a combination of progressive features of the tax rules (e.g., the CCTC rate declines with income) and the income inelasticity of child care expenses. Finally, we find tax relief to be more progressive when we use potential income as a measure of ability-to-pay.

Among families that receive tax relief for child care expenses, the tax benefits average 1.24 percent of family income. While our results on the progressivity of tax relief indicate that this percentage varies systematically across income groups, tax relief is too small to influence the income distribution dramatically. However, tax relief also varies substantially 
across families with the same income. This variation within income groups suggests that tax relief for child care changes household tax liabilities (and after-tax incomes) depending on the ages and number of children in the family, marital status of the parents, parent's education and choice of child care arrangements.

Our results using potential income suggest that household labor supply decisions are an integral part of how tax relief for child care is distributed. By reducing the after-tax price of child care, tax relief for child care can affect the labor market and child care decisions of households. In response to the lower price of child care, families may choose paid care over non-paid care, a different mode of market-provided care (e.g., child care center vs. family day care home), or a higher priced option within a particular mode of child care. Reducing the cost of child care may also affect the labor force participation or hours decisions of parents, especially mothers, since it raises the net of child care wage. To the extent tax relief induces significant changes in household labor supply and child care decisions, these behavioral responses will have implications for the distributional effects of any changes in the tax treatment of child care.

The remainder of the paper is organized as follows. The next section briefly describes the different features of tax relief, while Section II discusses various rationales for tax relief for child care. Section III presents evidence on the progressivity of tax relief, providing a comparison of results from the NCCS and tax return data. Section IV explores the determinants of the distribution of tax relief, including the various rules pertaining to tax relief for child care, how child care expenditures vary with income, and differences in family choices regarding child care. Section $\mathrm{V}$ discusses the results of using potential income to measure ability-to-pay, and Section VI discusses the implications of recent estimates of the demand for 
child care for how tax relief for child care can affect family behavior. The last section summarizes our results.

\section{Tax Relief for Child Care}

The U.S. income tax code has had special provisions for child care expenses since 1954. ${ }^{3}$ Initially, work-related child care expenses by low-income families were deductible from the tax base. In 1971, Congress expanded deductibility to cover a broader range of income groups, allowing families with an adjusted gross income up to $\$ 27,600$ to receive benefits. The Tax Reform Act of 1976 replaced the deductibility of expenses with a flat 20 percent credit for work-related child care expenses. The Economic Recovery Tax Act of 1981 (ERTA) modified the credit by introducing the current declining rate credit. ERTA also introduced Dependent Care Assistance Plans (DCAPs) which are employer-provided benefits that effectively give some taxpayers the choice between claiming the CCTC and deducting child care expenses from their taxable income. Subsequent tax reforms have made minor changes to the tax relief provisions, but they are substantially the same as enacted in 1981 . Below, we describe current features of the tax treatment of child care expenses.

In terms of eligibility, the two tax relief programs, the CCTC and DCAPs, are similar. Common features include: (1) Only the expenses for children under the age of 13 qualify; (2) Both parents, or the single parent, must work or be enrolled in school; (3) Child care expenses must be work-related; (4) Eligible expenses are limited to the earned income of the parent with the least income.

\footnotetext{
${ }^{3}$ Wolfman (1984) discusses the legislative history of child care provisions in the tax code and the legal debate surrounding the tax treatment of child care.
} 
The programs differ in the amount of eligible expenses, the value of the reduction in taxes, and in their administration. For the CCTC, qualified expenses are limited to $\$ 2,400$ for families with one child under age 13 and $\$ 4,800$ for families with more than one child under age 13. The amount of the credit depends on family income and child care expenses. For families with adjusted gross incomes (AGI) below $\$ 10,000$, the credit is 30 percent of qualified expenses. The rate of the credit falls by 1 percentage point for every $\$ 2,000$ of AGI until AGI equals $\$ 28,000$. For families with AGI above $\$ 28,000$, the credit rate is 20 percent. The credit is nonrefundable so the total credit is limited to the family's tax liability.

In contrast to the CCTC, DCAPs are flexible spending accounts in which employees can reduce their pre-tax income and use the reduction to pay for child care expenses. Employees cannot unilaterally create DCAPs; instead, employers must offer the plans as part of a fringe benefit package. Total family contributions to DCAPs are limited to $\$ 5,000$. Contributions are subject to neither income nor payroll taxes. The employee chooses a contribution level at the beginning of the year and contributions are subject to a "use-it-or-loseit" rule: the employee loses any contributions which are not withdrawn for child care expenses during the year. Since DCAP contributions lower taxable income, the DCAP's value roughly equals the family's marginal tax rate times the DCAP contribution.

A dollar of child care expenses cannot be subsidized through both the CCTC and the DCAP. However, using a DCAP does not completely preclude using the CCTC: each dollar contributed to a DCAP lowers the maximum expense qualifying for the CCTC by a dollar. Whether a family benefits more from a DCAP or the CCTC depends on its credit rate and its marginal tax rate. Since higher income families have lower credit rates and higher marginal tax rates, they may find it advantageous to use the DCAP rather than the CCTC. 
Consequently, the distribution of tax relief for child care is likely to be even more skewed toward middle- and upper-income families than the distribution of the benefits of the CCTC alone.

\section{Rationales for the Tax Treatment of Child Care}

In discussing the appropriate tax treatment of different items under an income tax, economists often start from the Haig-Simons definition of income. Under the Haig-Simons definition, income is defined as the monetary value of increases in potential consumption net of the costs incurred to earn that income. Under this definition, one could argue that workrelated child care expenses should be tax-deductible. Yet, the Haig-Simons criterion is not so easily applied in this case. For example, from the standpoint of a family with children in which both parents work, child care may be considered a necessary business expense. However, from the standpoint of a family deciding whether to have children, the future costs of child-rearing, including work-related child care, may arguably be considered more of a personal consumption decision than a necessary business expense. Despite the ambiguity under the Haig-Simons criterion, it is interesting to note that this argument for tax relief supports deductibility rather than a tax credit.

A broad range of other arguments can be made for and against tax provisions for child care. We divide these normative rationales into two groups: (1) equity and (2) efficiency (or incentive) arguments.

\section{Equity and the Tax Treatment of Child Care}

One goal of income taxation is to levy taxes in relation to a household's ability-to-pay. 
Yet, annual income is not necessarily a good measure of ability-to-pay. For example, a twoparent family with both parents in the labor force could have the same inherent ability-to-pay as a two-parent family with only one parent in the labor force, but its measured income would be different because of its labor supply choices. By giving the two-earner family tax relief for their child care expenses, the tax system makes a crude adjustment for this discrepancy between measured and actual ability-to-pay. A major flaw in this argument is that targeting child care is an imprecise way of distinguishing between one-earner and two-earner families since many two-earner families do not have child care expenses. A more precise adjustment would be a partial deduction of the earnings of the secondary earner as was the case in the U.S. in the early 1980s (see Feldstein and Feenberg, 1995).

Another possible justification for tax relief for child care is that differences in child care expenses drive a wedge between otherwise similar families. For example, the income tax code already recognizes that ability-to-pay can depend on family size by allowing personal exemptions. However, a uniform personal exemption does not distinguish between families with different costs of raising children, for example, if younger children are more expensive to raise than older school-aged children. Yet, this is more of an argument for making the personal exemption related to age than for special treatment for child care expenses. ${ }^{4}$ Another example would be that some families have access to low-cost, high-quality child care (e.g., care provided by a relative) while otherwise similar families do not have access to such care

\footnotetext{
${ }^{4}$ One obvious difference between making the personal exemption related to age and tax relief for child care is that targeting child care increases the chance that part of the additional after-tax income is spent on children. This concern is analogous to the sentiment that some people are more willing to have welfare for children than for parents. Of course, since money is fungible it is unclear whether this targeting changes overall expenditure patterns.
} 
(see Krashinsky, 1981). In this case, tax relief for child care adjusts tax payments to reflect differences in ability-to-pay driven by variation in the costs of care. Both of these arguments (distinguishing between two-earner and one-earner families and families with different child care expenses) are horizontal equity arguments for tax relief for child care.

In contrast to horizontal equity arguments, the notion of vertical equity is implicit in the CCTC's critics claims that most of the benefits of tax relief accrue to middle and upper-income families. ${ }^{5}$ These critics are often most concerned with the quality of child care in low-income households. Thus, they compare the distribution of benefits generated by direct expenditure programs targeted at low income families (e.g., Head Start) with the much less targeted tax relief programs. Vertical equity considerations have obviously affected the design of tax relief programs, including the declining credit rate and the limits on qualified expenditures.

\section{Efficiency and Tax Relief for Child Care}

In addition to horizontal and vertical equity rationales, tax relief for child care may be justified on efficiency (or incentive) grounds. One of the often-cited goals of subsidizing child care (whether through the tax system or direct expenditure programs) is to improve the quality of care received, particularly by children in low-income families. Society may care about the quality of care received by children in low-income families for equity reasons or because quality care generates social benefits just as we believe education generates benefits beyond the individual. If these external benefits are large, which may be especially likely for children from disadvantaged families, then subsidizing child care may increase efficiency. Tax relief

\footnotetext{
${ }^{5}$ See, for example, the statement of Douglas J. Besharov before the Senate Finance Committee (U.S. Senate, Committee on Finance, 1988).
} 
for child care reduces the marginal cost of care for many working families, ${ }^{6}$ which may encourage families to spend more per hour of care or to purchase more hours of care (if the child does not already have paid care for all of the parents' working hours). Higher cost care is commonly presumed to be of higher quality. Also, if market-provided care is of higher quality than the alternative form of care (e.g., self-care), then increasing the number of hours of paid care (for a given number of hours of parents' labor supply) increases the quality of care received.

Another often-cited goal of subsidizing child care is to influence the labor force participation and hours of work decisions of parents. A common assumption is that parents' labor supply decisions depend on the net of tax wage after accounting for child care expenses (the effective wage rate). Tax relief that is tied to labor force participation, under certain assumptions, increases the effective wage rate of the recipient (often the mother). ${ }^{7}$ Thus, tax relief is likely to influence the mother's labor force participation decision as well as her decision regarding how many hours to work. Changes in labor supply could affect efficiency in two ways. ${ }^{8}$ First, as is sometimes argued in the policy debate, if the tax treatment of child care induces low-income parents to work, then these parents may learn work skills that lead

\footnotetext{
${ }^{6}$ For families that do not have tax liabilities or exceed the qualified expense limits, tax relief does not affect the marginal cost of child care.

${ }^{7}$ In particular, it is necessary to assume that for every hour worked an hour of child care is needed.

${ }^{8}$ For a more detailed efficiency argument, see Krashinsky (1981) which presents a model with household production of child care and adult consumption. In the presence of a wage tax, the deductibility of child care expenses is the largest subsidy that can be justified on efficiency grounds. The optimal child care subsidy rate relative to the marginal wage tax rate depends on the relative elasticities between goods for time in the production of child care and adult consumption. He argues that reasonable assumptions about the substitutability of time and goods for producing child care and adult consumption leads to deductibility being close to optimal.
} 
them to self-sufficiency. Second, for higher income families, the tax treatment of child care could mitigate some of the inefficiencies created by the current tax treatment of two-income families (see Feldstein and Feenberg, 1995, for details on possible efficiency gains of alternative tax rules for families).

\section{The Distribution of Tax Relief for Child Care}

As discussed above, equity rationales for tax relief for child care include both vertical and horizontal equity arguments. The limited previous literature has focused solely on vertical equity. In this section, we address the vertical equity of tax relief for child care by evaluating the progressivity of tax relief using new data and a somewhat different methodology. In the next section, to capture some of the horizontal equity concerns, we examine the distribution of tax relief for child care across family characteristics, such as marital status and the number of children.

\section{Measuring Progressivity}

Tax relief for child care has been criticized as regressive because it is predominantly used by middle- and upper-income families (Robins, 1990). Critics point to nonrefundability of the credit as a particularly regressive feature. Yet, other features of the CCTC such as the credit rate declining with income are progressive. Contrary to the claims of regressivity of the CCTC, using 1979-1986 tax return data, Dunbar and Nordhauser (1991) find that the tax system with the CCTC is more progressive than without the CCTC.

Several methodological points may help explain this controversy over the progressivity of the CCTC. First, instead of focusing on families with children, Dunbar and Nordhauser 
study all households. Therefore, part of the CCTC's progressivity may simply be from the transfer of income from older families to families with children. This redistribution may increase the measured annual progressivity of the tax credit since older families are likely to have higher annual incomes than families with young children for lifecycle reasons. However, in the long run (assuming the tax credit stays in place), all families with children have an opportunity to qualify for the tax credit when their children are young. The effects of these transfers may be large since 6.5 percent of 1989 tax returns claim the CCTC (Internal Revenue Service, SOI Bulletin, Winter 1991-1992) compared with 29.9 percent of our sample of families with children.

Altshuler and Schwartz (1994) also examine the progressivity of the CCTC using tax return data. Unlike Dunbar and Nordhauser, they use average income over a number of years as a way of removing some transitory income shocks. Even with this alternative measure of ability-to-pay, they find results similar to Dunbar and Nordhauser. Yet, this approach still fails to capture lifecycle differences in income. Altshuler and Schwartz mitigate these lifecycle issues by restricting their sample to tax returns with dependent children. The NCCS gives us better information on family characteristics for determining whether a family is eligible for tax relief.

Second, Dunbar and Nordhauser use average measures of progressivity rather than estimating progressivity at different points in the income distribution. The CCTC could, on average, be progressive while still being regressive for low income groups. To measure progressivity at different points in the income distribution, we focus on how the average 
effective subsidy rate varies with income. ${ }^{9}$ The effective subsidy rate is the ratio of dollars of tax relief to household income. The average effective subsidy rate is the mean value of this ratio for the families in each income group. If the subsidy rate increases with income, then tax relief is regressive since higher income families are receiving proportionately more benefits. This measure of tax relief progressivity is the analog to average rate progression commonly used in tax analysis.

Finally, the progressivity of tax relief depends on the relationship between child care expenditures and income. If lower income families spend a larger fraction of their incomes on child care than higher income families, then, ceteris paribus, a subsidy to child care will be progressive. Unfortunately, the all-else-equal assumption fails to hold: labor force participation, household income and child care expenses are endogenously determined (see Connelly, 1992 and Blau and Robins, 1988). Therefore, income is a flawed ability-to-pay criterion for measuring progressivity. ${ }^{10}$

As an alternative ability-to-pay criterion, we construct a measure of household potential labor income. By eliminating differences in labor supply decisions from the ability-to-pay measure, our potential income measure assigns the same ability-to-pay to one-earner and twoearner families that have the same labor market opportunities. For the one-earner family, the ratio of actual income to potential income is low relative to the two-earner family. However, the two-earner family is more likely to benefit from tax relief. By treating these two families

\footnotetext{
${ }^{9}$ Altshuler and Schwartz examine progressivity at different points in the income distribution and find that the CCTC is progressive on average but regressive at low income levels.

${ }^{10}$ Atkinson and Stiglitz (1981, Chapter 9) discuss the logic of wanting to measure interpersonal differences in ability rather than outcomes for distributional issues.
} 
as equal, using potential income as a measure of ability-to-pay may reduce the perception that tax relief benefits are concentrated among relatively well-off families.

The Distribution of Benefits: NCCS Data

The NCCS includes 4,397 families with at least one child under age 13. ${ }^{11}$ Along with demographic and labor market data, the NCCS has data on the families' child care arrangements. The survey, conducted from October 1989 to April 1990, asked whether the family planned to use the CCTC for 1989 , whether either parent had access to a DCAP, and if the family used the DCAP, the family's contribution level. We exclude families with missing information on: (1) whether they plan to use the credit for 1989; (2) whether they paid for child care; (3) marital status; (4) employment status; (5) household income; or (6) whether they use a DCAP (given that they have access to a DCAP). This leaves a sample of 3,526 families.

The NCCS data have a number of advantages over tax return data. First, the NCCS isolates a cohort of families with children of eligible ages for tax relief. Second, in addition to information on the CCTC, the NCCS has information on access and participation in DCAPs. Third, the NCCS includes details on family structure, labor force participation, and child care expenses. This detailed demographic, labor market, and expenditure data allows us to separate eligible households from ineligible households. It also enables us to uncover whether certain types of families benefit more from tax relief than others, and it allows us to examine how the income elasticity of child care expenditures influences the distribution of benefits. A

\footnotetext{
"See Hofferth, Brayfield, Deich, and Holcomb (1991) for details on the NCCS.
} 
disadvantage of the NCCS for studying tax relief is the need to impute tax liabilities and the value of tax relief.

Table 1 presents the take-up rates for each type of tax relief by income level. Since some families use both programs, the table also reports the take-up rate for families using either form of tax relief. For the overall sample, 29.9 percent of families claim the CCTC but only 1.6 percent of families use DCAPs. Overall, 30.6 percent of families claim some form of tax relief. This percent increases with income: 25.6 percent of families with incomes below $\$ 25,000$ (about the bottom third of the income distribution) claim tax relief compared with 30.0 percent of families with incomes between $\$ 25,000$ and $\$ 40,000$ (roughly the middle third of the income distribution) and 36.5 percent of families with incomes above $\$ 40,000$. Tax relief from DCAPs goes to an affluent minority: only 1.6 percent of families use DCAPs but almost two-thirds (63.8 percent) of these families have incomes above $\$ 50,000$. Since DCAPs are such a small fraction of total tax relief, the pattern of the take-up rates for the CCTC mirror the take-up rates for all tax relief.

The main reason DCAPs are such a small fraction of tax relief is that few families have access to them. In our NCCS sample, only 7.7 percent of the households (272 out of 3526) report having access to a DCAP. ${ }^{12}$ Data from employer-based surveys suggest that more than 7.7 percent of families had access to DCAPs in the late 1980s; Hayes, Palmer and Zaslow

\footnotetext{
${ }^{12}$ One problem with self-reported data is that some people may be unaware of whether their employers offer DCAPs. We classify these families as not having access. In part, knowledge of access to DCAPs may be correlated with overall awareness of tax relief programs. In the NCCS data, families with access to DCAPs have a higher propensity to use the CCTC than families without access. While 29.9 percent of all families take the CCTC, 60.3 percent ( 35 out of 58 ) of families that use DCAPs also plan to use the CCTC for 1989. For families with access to DCAPs that do not contribute to the DCAP, 41.6 percent (89 out of 214) use the CCTC.
} 
(1990, p. 203) report that approximately 14 percent of large and small employers offered DCAPs. More recent data indicate that access to DCAPs is growing rapidly; according to a survey by Foster Higgins, benefits consultants, 45 percent of large employers offer DCAPs (reported in Rowland, 1994). Access to DCAPs is skewed toward higher income households. Relative to families in the bottom third of the income distribution, families in the top third of the income distribution are almost four times more likely to report having access to a DCAP. ${ }^{13}$ Furthermore, since DCAPs are less valuable than the CCTC for lower income households, the DCAP take-up rate among families with access to DCAPs rises sharply with income: 4.8 percent ( 2 out of 42 ) of households in the bottom third of the income distribution (and no families with income below $\$ 20,000$ ), 16.3 percent (13 out of 80 ) of the middle third and 28.7 percent ( 43 out of 150 ) of the top third use DCAPs.

The overall pattern of take-up rates of tax relief reflects several differences between high and low income families. First, at very low incomes, the take-up rate is low for working families because they have zero tax liability. Second, low income families are less likely to work and be eligible for tax relief. However, conditional on all parents in the family working during the previous year, the differences in take-up rates persist (not shown in the table). Third, low income working families are less likely to use paid child care and be eligible for tax relief. Conditioning on working and paying for child care, the take-up rates are similar across income groups: 50.5 percent of families in the bottom third of the income distribution claim tax relief compared with 54.2 percent of families in the top third. Thus, differences in

${ }^{13}$ For the bottom third of the income distribution, 3.4 percent ( 42 out of 1237 ) of households report having access to DCAPs compared with 7.0 percent ( 80 out of 1147) of the families in the middle third and 13.1 percent ( 150 out of 1142 ) of the families in the top third of the income distribution. 
family choices regarding child care and labor force participation at least partially explain the distribution in benefits across families of different income levels.

While the take-up rates increase with income, progressivity depends on the relationship of dollars of tax relief to income. Since the NCCS only asks whether a family takes the CCTC and not the value of the credit, we must impute the value of tax relief. First, we calculate the family's tax liability before the CCTC. Since the CCTC is nonrefundable, this tax liability is an upper bound for the value of the tax credit. We start by assuming that a family's AGI is the midpoint of their reported income range. Next, we impute taxable income by assuming the standard deduction is taken and basing the value of exemptions on the number of people in the household. ${ }^{14}$ The tax liability depends on taxable income and the rate schedule.

The value of the CCTC is the maximum of either the family's tax liability before the CCTC or the product of the family's credit rate and their qualifying annual expenses. The family's credit rate depends on AGI. We assume that all reported child care expenses are work-related and qualify for the credit. ${ }^{15}$ For families using DCAPs, the value of the DCAP

\footnotetext{
${ }^{14}$ The assumption that all families take the standard deduction is unlikely to affect the results since the CCTC subsidy rate is based on AGI which is calculated before taking either itemized or standard deductions. In some cases, we may understate the effect of the credit being nonrefundable since families with exceedingly high itemized deductions may not have taxable income to offset against the credit. Also, we may overstate the marginal tax rates of some families that itemize which would overstate the value of their using a DCAP.

15 The NCCS allowed respondents to report child care expenditures over different intervals (e.g., weekly, monthly or annually). Therefore, we calculate annual expenditures by multiplying weekly expenditures by 44 and monthly expenditures by 12 . The choice of 44 weeks per year is somewhat arbitrary but reflects that most families do not purchase work-related child care every week due to holidays and vacations. The choice of 12 months per year is also somewhat arbitrary. Nevertheless, it reflects our belief that expenditures reported on a monthly basis more accurately reflect days missed than expenditures reported on a weekly basis. As noted below, these assumptions lead to imputed tax credits which are similar to those found in tax return data.
} 
is the family's marginal tax rate times their DCAP contribution. The total value of tax relief is the sum of the values of the CCTC and the DCAP after accounting for the provision that each dollar spent can receive only one form of relief.

Column (5) reports the average dollar value of tax relief by income level for families claiming tax relief and reporting positive child care expenses during the last year. ${ }^{16}$ The average value of all tax relief is $\$ 446$ per recipient, while the average value of just the CCTC is $\$ 429$ (not shown in the table). The dollar value of tax relief is zero or quite small for families with incomes under $\$ 10,000$, reflecting nonrefundability of the CCTC. ${ }^{17}$ The value of tax relief rises quickly over the first few income groups and then flattens out over a broad range of incomes. The decline in the value of the credit between $\$ 17,500$ and $\$ 30,000$ may be partially explained by the credit rate declining with income. In addition, part of the increase in the value of tax relief at the top of the income distribution most likely reflects the increasing propensity to use DCAPs, which are more valuable than the CCTC. We return to explanations for the observed distribution of benefits in the next section.

Column (6) presents the mean effective subsidy rate conditional on claiming tax relief. Overall, tax relief for child care is 1.24 percent of the income of those taking the credit. For the bottom quintile of the income distribution, the subsidy rate increases with income suggesting that tax relief is indeed regressive. The effective subsidy rate reaches a maximum

${ }^{16}$ The numerator of the take-up rates includes all families claiming to use tax relief. However, some of these families reported having no paid child care during the previous year. We exclude these families from the calculations in columns (5), (6), and (7) since we cannot impute the value of tax relief.

${ }^{17}$ A puzzle in the data is why so many families with low incomes report receiving tax relief when their incomes suggest that the CCTC has no value to them. One possible explanation is that the respondents confused the CCTC with the refundable Earned Income Tax Credit. 
of 3.4 percent of income for the $\$ 15,000$ to $\$ 17,500$ income group. Above this income level, the mean effective subsidy rate steadily falls with income suggesting that over most of the income distribution tax relief is progressive.

While the effective subsidy rate declines with income for families with tax relief (column (6)), the propensity to receive tax relief increases with income (column (4)). The product of these two columns (column (7)) is the unconditional effective subsidy rate and may be interpreted as the mean effective subsidy rate for all families. ${ }^{18}$ As with column (6), the unconditional ESR increases through the bottom quintile of the income distribution and falls through the rest of the income distribution. Unlike the numbers in column (6), the unconditional ESR is roughly constant between incomes of $\$ 25,000$ and $\$ 100,000$ which suggests that tax relief is proportional to income through much of the income distribution. Therefore, even without conditioning on receiving tax relief, the tax programs is at least proportional over most of the income distribution of families with children.

\section{The Distribution of Benefits: Tax Return Data}

In using the NCCS data to measure the distribution of tax relief, we must impute the value of tax relief using self-reported information on income and expenditures. This imputation may differ from the actual tax situation of the household because either income or child care expenses reported on tax returns differ from the survey responses. Since the quality of our data may affect our conclusions, we construct similar statistics to those presented in

\footnotetext{
${ }^{18}$ The numbers in column (7) are not exactly equal to the product of columns (4) and (6) since column (6) is conditional on the family reporting paid child care expenses. In column (7), we treat families that claim to receive tax relief but report no paid child care expenses as having an ESR of zero. This assumption may lead to column (7) understating the mean ESR for all families.
} 
table 1 from tax return data for 1989 . The tax return data are from the public use sample prepared by the Statistics of Income Division of the Internal Revenue Service. In order to be as comparable to the NCCS data as possible, we use a sample of 39,459 tax returns of families with dependent children living at home. As discussed above, tax return data has the advantage of precisely measuring the value of the CCTC but has several disadvantages, such as not being able to isolate a cohort of families with children of eligible age for tax relief or measure tax relief from DCAPs. Therefore, our analysis of tax return data focuses entirely on the CCTC. Before comparing the distribution of the CCTC in the two data sets, it is instructive to compare whether the NCCS responses correspond with the aggregate number of families that take the credit reported by the IRS. Using the entire NCCS sample and sample weights that correct for potential non-responses, the NCCS data imply that 6.01 million families took the credit in 1988 and 7.09 million families planned to take the credit in $1989 .{ }^{19}$ In contrast, the SOI Tax Return samples indicate that 8.82 million families took the credit in 1988 but dropped to 5.92 million families in 1989 . The dramatic 33 percent decline in CCTC filers in the tax return data is most likely a response to changes in the tax rules which took effect in 1989 (e.g., claimants were required to report the Social Security Number of the child care

${ }^{19}$ We can offer two explanations for the 18 percent increase in claimants between 1988 and 1989 in the NCCS. First, families whose only child was under age one at the time of the survey could not have qualified for the CCTC in 1988 . This accounts for 430,0001989 claimants but is offset by claimants who were eligible in 1988 but were not surveyed by the NCCS (e.g., families with a youngest child who was 13 years old in 1988). This offset is probably small since families with youngest children age 13 rarely take the credit. Second, we expect that some respondents who did not know about the CCTC at the time of the survey said that they did not take it in the past but would take it in the future; that is, the NCCS raised these families' awareness of the CCTC. 
provider). ${ }^{20}$ In contrast, tax credit benefits grew steadily at an average 19 percent nominal growth rate between 1980 and 1988 and the number of claimants grew by about 10 percent per year according to data from the IRS Statistics of Income. Also, there is no evidence of any significant change in actual child care arrangements at this time. The proportion of children cared for either by a parent or by a relative stayed about the same between 1985 and 1990 (Hofferth et al., 1990, p. 101). Thus, the decline in CCTC filers likely reflects reduced tax evasion. The NCCS coinciding with these legislated changes complicates comparisons of the two data sets. Nevertheless, averaging across the two years, the two data sets produce similar numbers of total claimants.

Table 2 reports statistics on the distribution of the CCTC from the tax return data. ${ }^{21}$ For the sake of comparison, table 2 reports the same income ranges as in table 1; however, in table 2 we use each family's reported AGI as their household income rather than the midpoint of their income range as was necessary in table 1 . In addition, since the tax return data do not precisely identify children's ages, the take-up rates in table 2 use all tax returns with dependent children living at home as the denominator.

Despite the differences in the definition of the take-up rate, the take-up rates in the two samples have a similar pattern. The take-up rate generally increases with income but declines slightly for households with incomes over $\$ 100,000$. In addition, the average value of the

${ }^{20}$ The NCCS may not reflect this decline because at the time of the survey the respondents had not yet filed their 1989 tax return which would require the information reporting. Also, in responding to the NCCS, families that fraudulently claim the CCTC might not say that they claimed it on their tax returns.

${ }^{21}$ Since the sample oversamples high income tax returns, we use sampling weights to create statistics that are representative of the overall population. 


\section{1}

CCTC is quite similar in the two data sets though the value of the credit is slightly lower in the tax return data than the NCCS data ( $\$ 404$ vs. $\$ 429$ per recipient). As with the NCCS data, the tax return data indicate the dollar value of tax relief is zero or quite small for lowincome families, and the benefits rise quickly before flattening out over a broad range of incomes. As a percent of income, the CCTC rises through incomes of $\$ 15,000$ and falls fairly steadily for the rest of the income distribution. While the mean effective subsidy rate peaks at a lower income in the tax return data, this income level represents a larger fraction of the population than it does in the NCCS data. Thus, the general conclusion that tax relief is regressive at low income levels and progressive for most of the income distribution holds using tax return data as well as with the NCCS data.

Despite these similarities, there are some notable differences between the two data sets. Unlike the NCCS data, the tax return data does not have a positive take-up rate at low income levels. This suggests that the low-income families who claim to receive tax relief in the NCCS either answered the tax relief question incorrectly or their AGI exceeds what they report in the NCCS. At high income levels, the imputations using the NCCS overstate the value of tax relief relative to the tax return data. ${ }^{22}$ Also, in the various income ranges, the mean dollars received can vary substantially between the two data sets. These differences are most noticeable at the tails of the income distribution where some of the sample sizes are quite

${ }^{22}$ A small portion of this difference is from including DCAPs in our measure of tax relief in table 1. Since the number of families using both a DCAP and the CCTC is small, the NCCS imputations for just the CCTC are typically similar to the imputations for all tax relief. However, for the $\$ 125,000$ to $\$ 150,000$ income range, the NCCS data suggest a mean value of all tax relief of $\$ 633$ for families taking tax relief but a mean value of the CCTC of $\$ 256$ for families taking the CCTC. This difference highlights the importance of examining both programs simultaneously. 
small. $^{23}$

\section{Determinants of the Distribution of Tax Relief}

Several factors combine to generate the pattern of benefits from tax relief described above. These factors include the various rules pertaining to tax relief for child care, how child care expenditures vary with income, and differences in family choices regarding child care. In this section, we explore each of these determinants of the distribution of benefits from tax relief for child care.

\section{Program Features}

In addition to the declining credit rate, three features of tax relief affect the distribution of benefits: (1) nonrefundability; (2) limits on the maximum qualified expense; and (3) the earnings test that limits qualified expenses to the earnings of the parent with the lowest earnings. We examine the first and second of these features with both the NCCS and tax return data; for the earnings test, we use only the tax return data since the earnings data in the NCCS is subject to relatively large measurement error.

Nonrefundability restricts the CCTC's benefits to low income families with positive tax liabilities. As a consequence, it is difficult to measure how nonrefundability affects the take-up

${ }^{23}$ To test whether these differences are statistically significant, we compare the sample of CCTC observations in the two samples with a Mann-Whitney rank sum test for each income range. The null hypothesis of this non-parametric test is that the two samples are drawn from the same distribution. We reject this null hypothesis at the $95 \%$ confidence level in eight of the eighteen income ranges: $\$ 7,500$ $\$ 10,000, \$ 15,000-\$ 17,500$, and all of the ranges between $\$ 30,000-\$ 100,000$. In these higher income groups, our imputations from the NCCS overstate the value of the credit which would tend to bias the results towards finding the credit to be regressive. 
rate. Changing the tax rules may induce several types of behavioral responses, such as more parents working, more children being cared for by paid child care providers, and more families filing tax returns. These behavioral responses may be especially important for families that do not have a positive tax liability. We do not impute any behavioral changes. Instead, we calculate the fraction of families that have a positive tax liability before the CCTC but do not owe taxes after the credit. For these families, nonrefundability binds at the margin. Using the NCCS data, we estimate that half of the families with incomes below $\$ 17,500$ with positive tax liabilities before the CCTC paid no taxes after the CCTC. Thus, nonrefundability promotes regressivity at low incomes. The tax return data, reported in column (5) of table 2 , suggests that non-refundability binds less frequently: 29.5 percent of families with incomes below $\$ 17,500$ who take the CCTC have a credit that is at least as large as their tax liability before the credit. ${ }^{24}$

Qualified expense limits place an upper limit on the amount of tax relief a family can receive. ${ }^{25}$ Since higher income families typically spend more on child care, one would expect these limits to have a greater impact on higher income families. Using the NCCS data, we estimate that the expense limits bind for 29.1 percent of all families. The fraction of families for which the limits bind increases substantially with income: for families in the bottom third of the income distribution, we estimate that the limits bind for 20.2 percent of families

\footnotetext{
${ }^{24}$ However, the $\$ 17,500$ income cut-off represents 30 percent of the population in the tax return data compared to only 20 percent of the NCCS sample.

${ }^{25}$ For families with only one child under 13 years old, the DCAP limit of $\$ 5000$ is considerably greater than the CCTC limit of $\$ 2400$. Of the 38 families that report their annual DCAP contributions, 21 have only one eligible child. Of these one child families, two report contributions of $\$ 2400$ and eight report contributions greater than $\$ 2400$. Thus, for these families, the ability to use the DCAP for more expenses than the CCTC is an important difference between the two programs.
} 
compared to 35.9 percent of families in the top third of the income distribution. By limiting the benefits of the relatively well-off, these expense limits increase the progressivity of tax relief. As reported in column (6) of table 2, the tax return data confirm this result. Overall, the limit binds for 22.2 percent of all families but it binds for 36.7 percent of families with AGI above $\$ 100,000$.

The earnings test could affect the distribution of benefits if secondary earners in certain income ranges tend to have lower earnings than secondary earners in other income ranges. Column (7) of table 2 does not suggest a systematic link between the earnings test binding and the level of income. Overall, the earnings test binds for 2.1 percent of families that take the CCTC. This limit binds most frequently for the bottom third of the income distribution and for the highest income groups.

\section{Income Elasticity}

The distribution of tax relief benefits for child care also depends on the income elasticity of expenditures. Subsidizing a good at a constant rate can be either progressive or regressive depending on whether the good is income inelastic or elastic. As a simple measure of the income elasticity of child care purchases, we calculate how the median expenditure share varies with income. The median expenditure share for families with child care expenses falls from 9.1 percent in the lowest third of the income distribution to 2.8 percent for the top third. While child care expenditures rise with income, this falling expenditure share suggests that child care expenses are income inelastic. Thus, it is not surprising that in the portion of the income distribution that faces a constant subsidy rate, we find that tax relief for child care is progressive. 


\section{Family Characteristics}

While the tax code specifies the maximum value of tax relief, the actual tax benefit a family receives depends on certain family characteristics, such as the number of children, and on the family's labor supply and child care choices. Many of these decisions are endogenous to government policies toward child care. We do not attempt to examine specific behavioral responses with respect to tax policy. Instead, in an effort to address horizontal equity concerns, our goal is simply to uncover whether certain types of families benefit more from tax relief than others. Therefore, in this section, we examine the distribution of tax relief for child care across family characteristics.

A parent's marital status is likely to have a strong influence on the household's labor supply and child care decisions. As a consequence, the benefits of tax relief for child care are likely to vary according to marital status. Table 3 presents the NCCS information from table 1 for single and two-parent families. Several differences emerge: first, the income distributions of the two types of households are dramatically different. Over half of single-parent families have incomes below $\$ 17,500$ while over half of married households have incomes over $\$ 35,000$. Second, 38.4 percent of single-parents report receiving tax relief, a substantially higher percentage than the 28.3 percent of married households that report receiving tax relief. This greater propensity to claim tax relief probably reflects that more single-parent households meet the work requirements than married couples. Third, the mean value of tax relief for married families receiving relief exceeds that of single-parent families receiving relief $(\$ 467$ vs. \$392). However, conditional on income, single-parent families typically receive more tax relief than two-parent families. This difference is most prominent at low incomes where differences in the value of exemptions for single heads of households and married families 
mean that single-parent families have higher tax liabilities for any given level of AGI. Also, married couples may rely less on market-provided child care than single-parents since couples can share child care responsibilities. Finally, the mean ESR for single-parents is 1.7 percent of income, much larger than the mean ESR of married couples of 1.1 percent of income. The differences in take-up rates and ESRs suggest that tax relief for child care redistributes income from married households to single-parent households within the cohort of families with children. $^{26}$

As a way of characterizing the relationships between family characteristics and tax relief for child care, we regress whether a family claims tax relief and the value of this tax relief (conditional on receiving tax relief) on various family characteristics. We include information on the age of the youngest child in the family, the number of children in each of four age groups ( 0 - 2 years old, 3 - 5 years old, $6-12$ years old, and $13-18$ years old), the mother's age and number of years of schooling (for families with missing information on the mother, we use the father's age and years of schooling), marital status, whether a relative is available who could assist with child care, the primary child care arrangement of the youngest child in the family, and the logarithm of the midpoint of the family's reported income range. ${ }^{27}$

The first column of table 4 presents results from a probit regression of whether a family claims to receive tax relief. The results indicate that families whose youngest child is

\footnotetext{
${ }^{26}$ In terms of progressivity or regressivity within each sample, the two samples display the same peaked shape pattern of ESRs as in the combined sample.

${ }^{27}$ Since the income variable is reported as a range, we include separate variables for each income group that are equal to the logarithm of the midpoint of the range for people reporting income in that range and zero for families reporting income outside of the range.
} 
older are less likely to receive tax relief. Thus, at a point in time, tax relief is associated with families with younger children. Families with more children tend to be less likely to receive tax relief (though this relationship is not statistically significant for children between the ages of 3 and 5 , inclusive). Conditional on income, more educated mothers are more likely to receive tax relief, although this finding may reflect differences in labor force participation based on education levels. ${ }^{28}$ Consistent with the results in table 3 , single-parent families are more likely to receive tax relief than two-parent families. Relative to families that report parental care as the primary arrangement of the youngest child (the omitted category), families that use child care centers or family day care homes are the most likely to receive tax relief. ${ }^{29}$

The second column of table 4 reports the results from regressing the value of tax relief on family characteristics for families that claim tax relief. The dependent variable is the logarithm of the imputed value of tax relief for the family. The results indicate that families with more younger children receive more tax relief. For example, adding a four year old to a family that already receives tax relief will increase their tax relief by 26.2 percent. Again consistent with the results in table 3 , two-parent families claiming tax relief receive lower benefits than single-parent families claiming tax relief. In addition, families using either centers or family day care homes as the primary arrangement for their youngest child receive

\footnotetext{
${ }^{28}$ The interpretation of this coefficient is complicated by the fact that the family's income depends on the each parent's labor force participation decision and education level.

${ }^{29}$ Since the primary arrangement variable applies only to each family's youngest child but tax relief may result from expenditures on older children, we tried two types of sensitivity analyses. First, we excluded the primary arrangement variables. Second, we used a sample of families with only one child which required excluding the variables on the number of children in different age categories. For both of these alternative specifications, the remaining coefficients have a similar pattern to the reported results.
} 
the largest benefits. ${ }^{30}$ The model excludes a constant but has a full set of income variables since no families in the first two income groups receive tax relief. Conditional on other family characteristics, the income coefficients for the different income variables are typically around 0.44 and do not vary much by income. These coefficients suggest that the elasticity of tax benefits with respect to income is around 0.44 which is substantially less than one. Again, this finding is consistent with the benefits of tax relief being progressively distributed on average.

\section{Potential Income as a Measure of Ability-to-Pay}

The results in the previous section indicate that the tax relief received by a family depends upon its labor market and child care choices. In this section, we re-examine the vertical equity of tax relief using potential income (a measure of labor market opportunities) as a measure of ability-to-pay. We calculate potential labor income by arbitrarily multiplying each parent's hourly wage rate by 2600 hours per year (50 hours per week for 52 weeks). ${ }^{31}$ For parents without wage data (either because wage information is missing or a parent does not work in the market), we impute a market wage by estimating a wage equation using individual characteristics. ${ }^{32}$ We do not include capital income in our measure of potential income for

30 As with the probit, we estimated two alternative specifications: (1) excluding the primary arrangement variables; and (2) using families with only one child but excluding the age category variables. Again, these alternative specifications yield similar results to those reported in table 4 .

${ }^{31}$ Since we give each worker the same number of hours, the choice of 2600 hours per year only introduces an issue of the scale of potential income.

${ }^{32}$ In estimating wage equations for mothers, we include data on: age, experience, education, race, county of residence and squared-values of age, experience and education. We correct for biases created by labor force participation by using the two-stage technique outlined by Killingsworth (1983, pp. 148-153). We estimate similar wage equations for fathers except we do not have data on experience. In cases where the actual wage is missing and the predicted wage is negative, we assign the parent a predicted wage of zero. 
two reasons. First, to some degree differences in capital income arise from differences in households' preferences for the timing of consumption. Since we want to focus on differences in abilities rather than preferences, the concept of potential income should exclude capital income. Second, the NCCS data on capital income is sketchy so any attempt to include capital income would be imprecise.

We focus on married families to stress the differences between single-earner and twoearner families (or families with one full-time worker and one part-time worker). Using potential income has two effects on the distributional analysis. First, the ranking of households by potential income differs from the ranking by reported income. Second, for the effective subsidy rates, it changes the denominator. Since the choice of the maximum number of hours in a year is arbitrary, the scaling of potential income is arbitrary. Therefore, we focus on quartiles of the income distribution rather than absolute income levels. ${ }^{33}$

Figure 1 compares the take-up rates for married families using actual and potential income as the ability-to-pay criterion. The take-up rates for actual income correspond to those in column (6) of table 3. For both measures of ability-to-pay, the take-up rate increases monotonicly with ability-to-pay. However, the difference in take-up rates between the top and bottom quartiles is smaller when ability-to-pay is measured by potential income rather than reported income. This difference suggests that part of the pattern of take-up rates in the reported income distribution may come from child care expenses being a cost of having two incomes, which is positively correlated with having a higher reported income.

Figure 2 compares the conditional effective subsidy rate using the different ability-to-

${ }^{33}$ We approximate the quartiles of reported income for married households as: $\$ 0-25,000(24.6$ percent), 25,000 - 35,000 (25.0 percent), 35,000 - 50,000 (27.4 percent), and above 50,000 (23.0 percent). 
pay measures. Since potential income is about two-thirds larger than reported income, the average effective subsidy rate is about thirty percent lower. When households are ranked by reported income and the subsidy rate is defined using the midpoint of the reported income range, tax relief is regressive at low income levels (the effective subsidy rate rises with income) but is progressive above the lowest income quartile. Using potential income to measure ability-to-pay leads to a different conclusion: the effective subsidy rate falls throughout the distribution of potential income. Furthermore, the percentage difference in the effective subsidy rate between the top and bottom quartiles is higher when potential income is the measure of ability-to-pay. Both of these differences imply that tax relief is more progressive among married families that receive some relief when the measure of ability-to-pay is potential, rather than reported, income. ${ }^{34}$ We interpret this difference as indicating that labor supply decisions are an integral part of how tax relief for child care is distributed.

\section{The Behavioral Effects of Tax Relief for Child Care}

By reducing the after-tax price of child care, tax relief for child care can affect the labor market and child care decisions of households. These behavioral effects may be the unintended consequences of tax policy or they may serve certain government policy objectives. As discussed earlier, one of the government's goals in providing tax relief for child care might be to encourage work effort by low-income households. Alternatively, one of the

${ }^{34}$ Examining the unconditional effective subsidy rates (the product of the take-up rates and the conditional mean effective subsidy rates) confirms the result that tax relief is more progressive when abilityto-pay is measured by potential income. For reported income, the distribution of the unconditional effective subsidy rate is: 0.22 (bottom quartile), $0.34,0.35$, and 0.31 . For potential income, this pattern is: 0.19 , $0.25,0.25,0.18$. However, even with potential income as the measure of ability-to-pay, the unconditional mean of the effective subsidy rates suggests some regressivity at low ability-to-pay levels. 
government's goals might be to encourage the purchase of higher priced, presumably higher quality, care. Tax relief that is tied to labor force participation and the use of market care (as are the CCTC and the DCAP) has the potential to achieve both these goals.

Tax relief reduces the marginal cost of care and, thus, raises the net of child care wage. For example, of those households paying for care, families with an employed mother spend on average $\$ 1.56$ per hour of care (Hofferth et al. 1991, p. 133). ${ }^{35}$ Nearly 64 percent of employed mothers pay less than $\$ 1.50$ per hour, whereas only 2 percent pay $\$ 5.00$ or more per hour (Hofferth et al. 1991, p. 133). On the other hand, employed mothers of preschoolage children earn a median wage of $\$ 8.17$ per hour, while 25 percent of employed mothers earn less than $\$ 5.50$ per hour and 75 percent earn less than $\$ 12.50$ per hour. ${ }^{36}$ Thus, for a mother earning the median wage, paying the average hourly child care cost and facing a marginal tax rate on labor income of 25 percent from the combined state and federal income and payroll taxes, a 30 percent tax credit raises the after-tax net of child care wage approximately 10 percent. ${ }^{37}$ The question for tax policy is whether the tax relief programs are likely to induce significant changes in family labor market and child care decisions. To the extent tax relief induces significant changes in household behavior, these behavioral responses will have implications for the distributional effects of any changes in the tax treatment of child care.

The literature on the behavioral effects of child care subsidies had been fairly limited old.

${ }^{35}$ This figure represents expenditures for the primary arrangement of the youngest child under 5 years

${ }^{36}$ These figures are based on the authors' calculations using the full sample from the NCCS.

${ }^{37}$ This percentage increase in the wage is calculated as: $(.30)(\$ 1.56) /[(1-.25)(\$ 8.17)-\$ 1.56]$. 
until recently. The pioneering study in this field was by Heckman (1974). Heckman's research, which relied on an indirect measure of child care costs, provided the first evidence of a potentially large effect of child care costs on mothers' labor force participation. However, it was not until a study by Blau and Robins (1988) that direct evidence was found that child care costs have a significant effect on married women's labor supply as well as the demand for market care. Using data from the 1980 baseline household survey of the Employment Opportunity Pilot Projects (EOPP), Blau and Robins estimated a model of family labor supply incorporating both market and nonmarket care. They estimated the price elasticity of employment to be -0.38 and the price elasticity of market care to be -0.34 .

Using data from the 1984 Panel of the Survey of Income and Program Participation (SIPP), more recent studies by Connelly (1992), Ribar (1992), and Michalopoulos, Robins, and Garfinkel (1992) confirm the results of Blau and Robins. The results of all of these studies are summarized in table 5. Connelly examined the effect of child care costs on married women's labor force participation and found the participation rate to be sensitive to the average cost of child care. In particular, she estimated the price elasticity of employment to be -0.20 . Connelly did not examine the decision to purchase market care.

Ribar analyzed the demand for market and nonmarket care as well as the decision of married women to enter the labor market. He too found that hourly child care costs have a negative effect on the labor force participation rate of married women and on their decision to purchase market care. However, Ribar estimated elasticities considerably larger than those found in previous studies. In particular, he estimated the price elasticity of employment to be 0.74 and the price elasticity of market care to be -1.86 . Ribar suggests that the smaller elasticities found in the previous studies are the result of using expenditures per week or per 
hour of work rather than expenditures per hour of care per child. Thus, he asserts the previous studies captured combinations of cost and utilization effects.

Finally, Michalopoulos, Robins, and Garfinkel estimated a structural model in which the decision to purchase market care is made simultaneously with the mother's decision to participate in the labor force. ${ }^{38}$ Michalopoulos et al. found price effects on women's labor supply considerably smaller and price effects on child care expenditures greater than the effects estimated by other researchers. However, it should be noted, in contrast to the other studies reported here, the elasticities in Michalopoulos et al. were calculated for mothers who already work and purchase care rather than for the full sample of women. Michalopoulos et al. estimated the elasticity of hours worked with respect to the child care subsidy rate to be 0.0018 and the elasticity of child care expenditures to be 0.20 .

Since Michalopoulos et al. employ a structural model to estimate the employment decision of the mother and the decision to purchase market care, they are able to estimate directly the effect of a change in child care subsidies on child care expenditures and mothers' labor supply. In particular, the structural estimates are used to simulate the effects of proposed changes to the child care tax credit. Since nonrefundability has been criticized as a particularly regressive feature of the CCTC, Michalopoulos et al. simulate the effects of making the CCTC refundable. In addition, they simulate the effects of making the declining subsidy rate (a progressive feature of the CCTC) more progressive. ${ }^{39}$ They find the behavioral response to

\footnotetext{
${ }^{38}$ Ribar (1992) employed a partially structural approach in which a reduced form labor supply equation and structural child care demand equations are estimated.

${ }^{39}$ In particular, Robins has proposed a refundable credit with a credit rate of $80 \%$ for families with incomes below $\$ 10,000$. He has proposed gradually reducing the rate to $20 \%$ for families with incomes of $\$ 40,000$ and phasing it out entirely for families with incomes exceeding $\$ 60,000$.
} 
the refundable credit to be small, while the effects of the more progressive credit are more pronounced. In addition, most of the behavioral response is an increase in child care expenditures rather than an increase in labor supply. For example, among married mothers there is a 21.1 percent increase in hours worked and a 508 percent increase in child care expenditures. ${ }^{40}$

Henderson (1989) points out that if the labor market effects are large enough, tax relief for child care could pay for itself through the higher labor income taxes collected on the additional labor supply. This argument depends on the size of the labor market response, the magnitude of the subsidy, and the marginal tax rates on labor income. Using labor supply estimates from Blau and Robins (1988), Henderson calculates that by eliminating the CCTC, the government's revenue gain would be less than half the static estimate of the tax expenditure since families would reduce their labor supply and pay less in income and payroll taxes.

\section{Conclusion}

The tax treatment of child care expenditures is a complex area of tax policy. The debate over how to design these policies addresses issues of horizontal and vertical equity as well as questions of efficiency. We examine the distributional effects of the tax treatment for child care within this framework.

By evaluating the progressivity of tax relief, we address concerns regarding the vertical equity of tax relief. Using reported income as the measure of ability-to-pay, our results support both the critics of child care tax relief and previous research that finds the CCTC to be

\footnotetext{
${ }^{40}$ The behavioral response is even more pronounced for single mothers.
} 
progressive: among a sample of families with children, tax relief is regressive through the lowest quintile of the income distribution but progressive throughout the remainder of the income distribution. The regressivity at low income levels is primarily driven by nonrefundability of the credit, while the progressivity is driven by a combination of program features, including the declining credit rate and limits on qualified expenses, and the income inelasticity of child care expenses. When potential income is used as the measure of ability-topay, the benefits of tax relief appear progressive throughout the income distribution. This difference in conclusions from using the different ability-to-pay standards emphasizes the importance of defining which families are similar for interpreting equity issues.

To address some of the concerns regarding the horizontal equity of tax relief, we examine the distribution of benefits across family characteristics. We find single-parent families are more likely to receive tax relief and, conditional on income, receive larger amounts of tax relief. In addition, among families with at least one child under age 13, the probability of using the CCTC or a DCAP decreases with the number of children. However, conditional on receiving tax relief, the value of tax relief increases with the number of children under age 13 and this increase depends on the age of the child. As one might expect, families with pre-school age children receive larger benefits than families with school age children. Finally, larger tax relief benefits accrue to families that use child care centers or family day care homes as the primary arrangement for their youngest child than families that use other modes of care.

Clearly, differences in family labor market and child care decisions are important in determining the distribution of benefits from the current tax policy. Econometric studies of women's labor supply and child care decisions suggest that tax policy can have substantial 
behavioral effects. These behavioral responses will have implications for the distributional effects of any changes in the tax treatment of child care. 


\section{References}

Altshuler, Rosanne and Amy Ellen Schwartz. 1994. "A Note on the Progressivity of the Child Care Tax Credit: Snapshot versus Time-Exposure Incidence," photocopy, Rutgers University.

Atkinson, Anthony B. and Joseph E. Stiglitz. 1980. Lectures on Public Economics, New York: McGraw-Hill.

Blau, David and Philip Robins. 1988. "Child Care Costs and Family Labor Supply," Review of Economics and Statistics, 70:374-381.

Connelly, Rachel. 1992. "The Effect of Child Care Costs on Married Women's Labor Force Participation," Review of Economics and Statistics, 82:83-90.

Dunbar, Amy and Susan Nordhauser. 1991. "Is the Child Care Credit Progressive?," National Tax Journal, 44:519-528.

Feldstein, Martin and Daniel Feenberg. 1995. "The Taxation of Two Earner Families," in Martin Feldstein and James M. Poterba, eds., Microeconometric Foundations of Household Taxation, University of Chicago Press, forthcoming.

Garfinkel, Irwin, Daniel Meyer and Patrick Wong. 1990. "The Potential of Child Care Tax Credits to Reduce Poverty and Welfare Recipiency," Population Research and Policy Review, 9:45-63.

Hayes, Cheryl D., John L. Palmer, and Martha J. Zaslow. 1990. Who Cares for America's Children? Child Care Policies for the 1990s, Washington, D. C.: National Academy Press.

Heckman, James J. 1974. "Effects of Child Care Programs on Women's Work Effort." Journal of Political Economy, 82:136-163.

Henderson, David R. 1989. "The Supply Side Tax Revenue Effects of the Child Care Tax Credit," Journal of Policy Analysis and Management, 8:673-675.

Hofferth, Sandra L., April Brayfield, Sharon Deich, and Pamela Holcomb, (1991), National Child Care Survey, 1990, Washington, DC: The Urban Institute Press.

Killingsworth, Mark R. 1983. Labor Supply, Cambridge: Cambridge University Press.

Krashinsky, Michael. 1981. "Subsidies to Child Care: Public Policy and Optimality," Public Finance Quarterly, 9:243-269.

Michalopoulos, Charles, Philip K. Robins, and Irwin Garfinkel. 1992. "A Structural Model 
of Labor Supply and Child Care Demand," The Journal of Human Resources, 27(1):166-203.

Ribar, David C. 1992. "Child Care and the Labor Supply of Married Women: Reduced Form Evidence," The Journal of Human Resources, 27(1):134-65.

Robins, Philip K. 1990. "Federal Financing of Child Care: Alternative Approaches and Economic Implications," Population Research and Policy Review, 9:65-90.

Rowland, Mary. 1994. "A Tax Break that Few Employees Use," New York Times, November 19, page 38 .

U.S. Senate Committee on Finance. 1988. Hearing on the Federal Role in Child Care. September 22, 1988.

Wolfman, Brian. 1984. "Child Care, Work, and the Federal Income Tax," The American Journal of Tax Policy, 3:153-193. 
TABLE 1: Tax Relief by Income Level for 1989

\begin{tabular}{|c|c|c|c|c|c|c|c|c|}
\hline & ncome $(\$ 000 \mathrm{~s})$ & $\begin{array}{l}\text { Cum. \% of } \\
\text { income dist. } \\
\text { (1) }\end{array}$ & $\begin{array}{c}\text { \% taking } \\
\text { CCTC } \\
(2)\end{array}$ & $\begin{array}{c}\% \text { using } \\
\text { DCAP } \\
\text { (3) }\end{array}$ & $\begin{array}{c}\text { \% with some } \\
\text { tax relief } \\
\text { (4) }\end{array}$ & $\begin{array}{l}\text { Mean tax relief for } \\
\text { families with tax } \\
\text { relief } \\
\text { (5) }\end{array}$ & $\begin{array}{l}\text { Mean ESR for } \\
\text { families with tax } \\
\text { relief } \\
(6)\end{array}$ & $\begin{array}{l}\text { Mean ESR for } \\
\text { all families } \\
\text { (7) }\end{array}$ \\
\hline & $<5$ & 3.4 & 21.0 & 0.0 & 21.0 & $\$ 0.00$ & 0.0 & 0.00 \\
\hline 5 & -7.5 & 5.9 & 15.7 & 0.0 & 15.7 & 0.00 & 0.0 & 0.00 \\
\hline 7.5 & -10 & 9.9 & 26.4 & 0.0 & 26.4 & 12.00 & 0.14 & 0.02 \\
\hline 10 & -12.5 & 13.3 & 30.6 & 0.0 & 30.6 & 147.44 & 1.31 & 0.30 \\
\hline 12.5 & $5-15$ & 17.0 & 24.8 & 0.0 & 24.8 & 309.26 & 2.25 & 0.38 \\
\hline 15 & - 17.5 & 20.0 & 29.0 & 0.0 & 29.0 & 545.86 & 3.36 & 0.69 \\
\hline 17.5 & $5-20$ & 23.5 & 25.6 & 0.0 & 25.6 & 465.99 & 2.49 & 0.46 \\
\hline 20 & -25 & 35.1 & 26.8 & 0.5 & 26.8 & 425.53 & 1.89 & 0.40 \\
\hline 25 & -30 & 47.4 & 27.7 & 1.2 & 28.4 & 404.03 & 1.47 & 0.33 \\
\hline 30 & -35 & 57.7 & 28.4 & 0.8 & 29.0 & 410.53 & 1.26 & 0.28 \\
\hline 35 & -40 & 67.6 & 32.8 & 1.4 & 33.0 & 461.41 & 1.23 & 0.33 \\
\hline 40 & -45 & 74.8 & 26.1 & 2.0 & 27.3 & 484.64 & 1.14 & 0.23 \\
\hline 45 & -50 & 81.2 & 36.7 & 0.4 & 36.7 & 486.85 & 1.02 & 0.30 \\
\hline 50 & -75 & 93.4 & 37.8 & 4.9 & 40.1 & 558.19 & 0.89 & 0.31 \\
\hline 75 & -100 & 97.3 & 44.5 & 8.0 & 46.7 & 617.43 & 0.71 & 0.30 \\
\hline 100 & -125 & 98.3 & 27.8 & 5.6 & 30.6 & 730.93 & 0.65 & 0.16 \\
\hline 125 & -150 & 99.0 & 30.4 & 8.7 & 30.4 & 633.14 & 0.46 & 0.14 \\
\hline & $>150$ & 100.0 & 27.8 & 2.8 & 27.8 & 640.44 & 0.37 & 0.09 \\
\hline \multicolumn{2}{|c|}{ TOTAL } & - & 29.9 & 1.6 & 30.6 & 446.02 & 1.24 & 0.30 \\
\hline
\end{tabular}

The sample includes 3,526 families. Income ranges are in thousands of dollars. The take-up rates in columns (2) - (4) are from responses to questions on whether the family takes the CCTC or uses a DCAP. Columns (5) and (6) condition on whether a family claims to receive either form of tax relief and reports paying for some regular child care. ESR stands for the effective subsidy rate expressed as a percent of income. Column (7) is the ESR averaging over all families and assigning an ESR of zero to families that claim to use tax relief but do not report child care expenses. 
40

TABLE 2: CCTC by Income Level for 1989, Tax Return Data

\begin{tabular}{|c|c|c|c|c|c|c|c|c|}
\hline \multicolumn{2}{|c|}{ Income $(\$ 000$ s) } & $\begin{array}{l}\text { Cum. \% of } \\
\text { income dist., } \\
\text { returns with dep. } \\
\text { (1) }\end{array}$ & $\begin{array}{l}\text { \% taking } \\
\text { CCTC, returns } \\
\text { with dep } \\
\text { (2) }\end{array}$ & $\begin{array}{l}\text { Mean CCTC for } \\
\text { families taking } \\
\text { CCTC } \\
\text { (3) }\end{array}$ & $\begin{array}{c}\text { Mean ESR } \\
\text { for families } \\
\text { taking CCTC } \\
\text { (4) }\end{array}$ & $\begin{array}{l}\% \text { for which } \\
\text { refundability } \\
\text { binds } \\
\text { (5) }\end{array}$ & $\begin{array}{l}\% \text { for which } \\
\text { expense limit } \\
\text { binds } \\
\text { (6) }\end{array}$ & $\begin{array}{l}\% \text { for which } \\
\text { earnings limit } \\
\text { binds } \\
\text { (7) }\end{array}$ \\
\hline & $<5$ & 5.8 & 0.00 & $\$ 0.00$ & 0.0 & -- & - & -- \\
\hline 5 & -7.5 & 9.9 & 0.00 & 0.00 & 0.0 & -- & -- & - \\
\hline & -10 & 14.4 & 2.80 & 129.49 & 1.37 & 66.5 & 13.9 & 3.16 \\
\hline & -12.5 & 19.6 & 10.09 & 289.33 & 2.54 & 61.2 & 25.4 & 3.38 \\
\hline 12.5 & -15 & 24.7 & 12.25 & 412.11 & 3.02 & 35.2 & 27.4 & 1.41 \\
\hline & -17.5 & 29.4 & 16.15 & 401.97 & 2.48 & 15.3 & 16.6 & 2.23 \\
\hline 17.5 & -20 & 33.8 & 18.56 & 465.80 & 2.50 & 12.4 & 20.1 & 4.95 \\
\hline 20 & -25 & 42.4 & 20.27 & 436.04 & 1.96 & 3.8 & 23.2 & 3.25 \\
\hline 25 & -30 & 50.1 & 18.67 & 388.64 & 1.41 & 0.53 & 22.1 & 1.56 \\
\hline 30 & -35 & 57.8 & 20.64 & 356.12 & 1.10 & 0.41 & 15.2 & 2.15 \\
\hline 35 & -40 & 65.0 & 18.58 & 416.64 & 1.12 & 0.0 & 25.3 & 1.26 \\
\hline 40 & -45 & 71.6 & 19.31 & 374.07 & 0.88 & 0.36 & 17.2 & 2.59 \\
\hline 45 & -50 & 76.9 & 18.58 & 379.25 & 0.80 & 0.0 & 21.1 & 1.18 \\
\hline 50 & -75 & 91.6 & 21.60 & 421.90 & 0.71 & 0.0 & 23.5 & 1.16 \\
\hline 75 & -100 & 95.9 & 19.90 & 445.19 & 0.53 & 0.0 & 27.5 & 2.13 \\
\hline 100 & -125 & 97.4 & 12.56 & 491.50 & 0.44 & 0.0 & 36.1 & 2.54 \\
\hline 125 & -150 & 98.2 & 12.88 & 475.98 & 0.35 & 0.0 & 34.7 & 2.04 \\
\hline & $>150$ & 100.0 & 9.74 & 484.19 & 0.23 & 0.0 & 38.6 & 5.27 \\
\hline TOT & & -- & 15.72 & 404.06 & 1.32 & 5.9 & 22.2 & 2.13 \\
\hline
\end{tabular}

The sample includes 39,459 tax returns from the public use sample prepared by the Statistics of Income Division of the IRS with dependent children living at home. Income ranges refer to AGI and are in thousands of dollars. The take-up rates in column (2) use all tax returns as the denominator. Columns (3) and (4) condition on whether a family receives a CCTC. ESR stands for the effective subsidy rate expressed as a percent of income. 
TABLE 3: Tax Relief by Income Level for 1989, by Marital Status

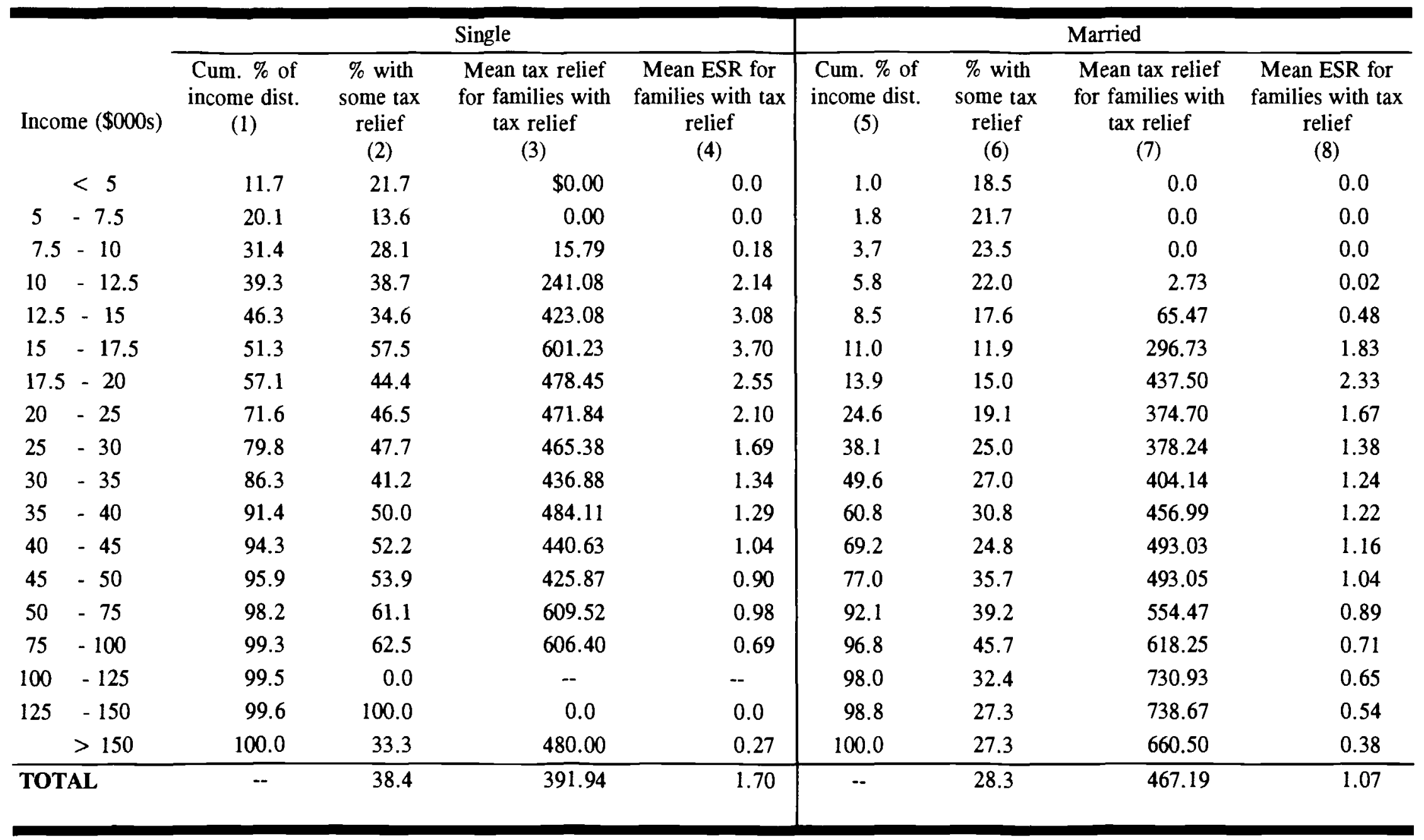

The sample includes 3,526 families of which 787 are single parent families and 2,739 are two-parent families. The columns correspond to the columns in table 1 . 
TABLE 4: Regression Analysis of Take-up Rates and Value of Tax Relief

\begin{tabular}{|c|c|c|c|c|}
\hline \multirow[b]{2}{*}{ Independent var.: } & \multicolumn{2}{|c|}{$\begin{array}{l}\text { Take-up Rate Probits } \\
\text { (1) }\end{array}$} & \multicolumn{2}{|c|}{$\begin{array}{l}\text { Value of Tax Relief, if } \\
\text { relief }>0 \\
\text { (2) }\end{array}$} \\
\hline & coef. & s.e. & coef. & s.e. \\
\hline Youngest child's age & $-0.076^{*}$ & 0.015 & -0.021 & 0.021 \\
\hline$\#$ kids age $\leq 2$ & $-0.302^{*}$ & 0.078 & 0.179 & 0.101 \\
\hline$\#$ kids $3 \leq$ age $\leq 5$ & -0.058 & 0.053 & $0.262^{*}$ & 0.066 \\
\hline$\#$ kids $6 \leq$ age $\leq 12$ & $-0.097 *$ & 0.035 & 0.012 & 0.048 \\
\hline$\#$ kids $13 \leq$ age $\leq 18$ & $-0.133 *$ & 0.042 & $-0.294^{*}$ & 0.066 \\
\hline Parent's age & 0.0001 & 0.005 & 0.005 & 0.007 \\
\hline Parent's education & $0.044^{*}$ & 0.013 & 0.032 & 0.017 \\
\hline Married (yes = 1) & $-0.405^{*}$ & 0.071 & $-0.225^{*}$ & 0.084 \\
\hline Relative present $($ yes $=1$ ) & -0.060 & 0.055 & 0.021 & 0.068 \\
\hline \multicolumn{5}{|l|}{ Main Arrangement: } \\
\hline Center & $1.238^{*}$ & 0.072 & $0.811 *$ & 0.096 \\
\hline Relative & $0.389 *$ & 0.076 & $0.463 *$ & 0.123 \\
\hline Sitter & $0.540^{*}$ & 0.146 & $0.433 *$ & 0.182 \\
\hline Fanily Day & $1.222^{*}$ & 0.085 & $0.867^{*}$ & 0.106 \\
\hline Self Care & 0.305 & 0.226 & -0.560 & 0.436 \\
\hline Other & 0.158 & 0.099 & 0.254 & 0.167 \\
\hline Income 1 & -0.003 & 0.038 & & \\
\hline Income 2 & -0.035 & 0.035 & & \\
\hline Income 3 & 0.008 & 0.031 & $0.235^{*}$ & 0.043 \\
\hline Income 4 & 0.030 & 0.031 & $0.375^{*}$ & 0.038 \\
\hline Income 5 & 0.016 & 0.030 & $0.454^{*}$ & 0.039 \\
\hline Income 6 & 0.042 & 0.030 & $0.503^{*}$ & 0.038 \\
\hline Income 7 & 0.017 & 0.029 & $0.464^{*}$ & 0.037 \\
\hline Income 8 & 0.030 & 0.026 & $0.468 *$ & 0.033 \\
\hline Income 9 & 0.043 & 0.025 & $0.455^{*}$ & 0.033 \\
\hline Income 10 & 0.032 & 0.025 & $0.438^{*}$ & 0.034 \\
\hline Income 11 & $0.049 *$ & 0.025 & $0.464^{*}$ & 0.033 \\
\hline Income 12 & 0.036 & 0.025 & $0.444^{*}$ & 0.034 \\
\hline Income 13 & $0.056^{*}$ & 0.025 & $0.451^{*}$ & 0.033 \\
\hline Income 14 & $0.054^{*}$ & 0.023 & $0.444 *$ & 0.033 \\
\hline Income 15 & $0.064 *$ & 0.024 & $0.447^{*}$ & 0.033 \\
\hline Income 16 & 0.039 & 0.030 & $0.457 *$ & 0.040 \\
\hline Income 17 & 0.019 & 0.032 & $0.454^{*}$ & 0.041 \\
\hline Income 18 & & & $0.426^{*}$ & 0.037 \\
\hline Intercept & 1.027 & 0.368 & & \\
\hline
\end{tabular}

Adj. R-square

0.98

The sample size is 3438 for the take-up probit and 764 for the value of tax relief regression. Parental care is the omitted category for primary arrangement. ${ }^{*}$ denotes coefficients that are statistically significant at the 95 percent confidence level. 
TABLE 5: Behavioral Effects of Tax Relief for Child Care

\begin{tabular}{llll}
\hline \multicolumn{1}{c}{ Study } & \multicolumn{1}{c}{ Data } & $\begin{array}{c}\text { Estimated elasticity of } \\
\text { employment }\end{array}$ & $\begin{array}{c}\text { Estimated elasticity of } \\
\text { market care }\end{array}$ \\
\hline Blau and Robins (1988) & $\begin{array}{l}1980 \text { baseline household survey of the } \\
\text { Employment Opportunity Pilot Projects } \\
\text { (EOPP) } \\
\text { 1984 Panel of the Survey of Income and } \\
\text { Program Participation (SIPP) } \\
\text { Connelly (1992) }\end{array}$ & -0.38 & -0.34 \\
Ribar (1992) & $\begin{array}{l}\text { Program Participation (SIPP) } \\
\text { 1984 Panel of the Survey of Income and } \\
\text { Michalopoulos, Robins, and Garfinkel (1992) }\end{array}$ & -0.74 \\
& Program Participation (SIPP) & $0.0018^{\mathrm{a}}$ & -1.86 \\
\end{tabular}

In contrast to the other studies, the Michalopoulos, Robins and Garfinkel results are for mothers who already work and purchase child care.

${ }^{a}$ Estimated elasticity of hours worked with respect to child care subsidy rate.

- Estimated elasticity of child care expenditures with respect to child care subsidy rate. 
Figure 1: Take-up Rates by Ability-to-pay Criteria

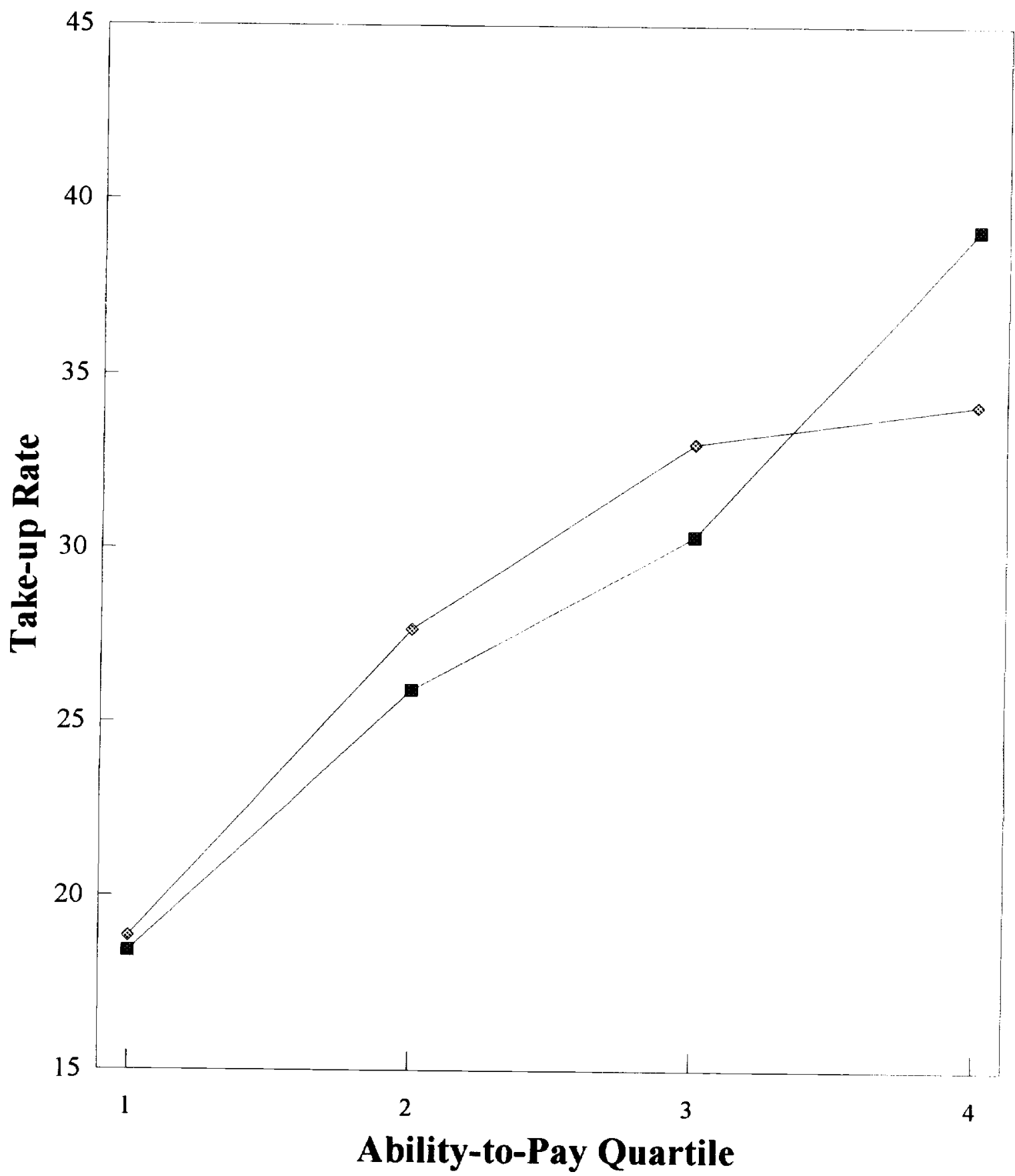

- Reported Income $\diamond$ Potential Income 
Figure 2: ESRs by Ability-to-pay Criteria

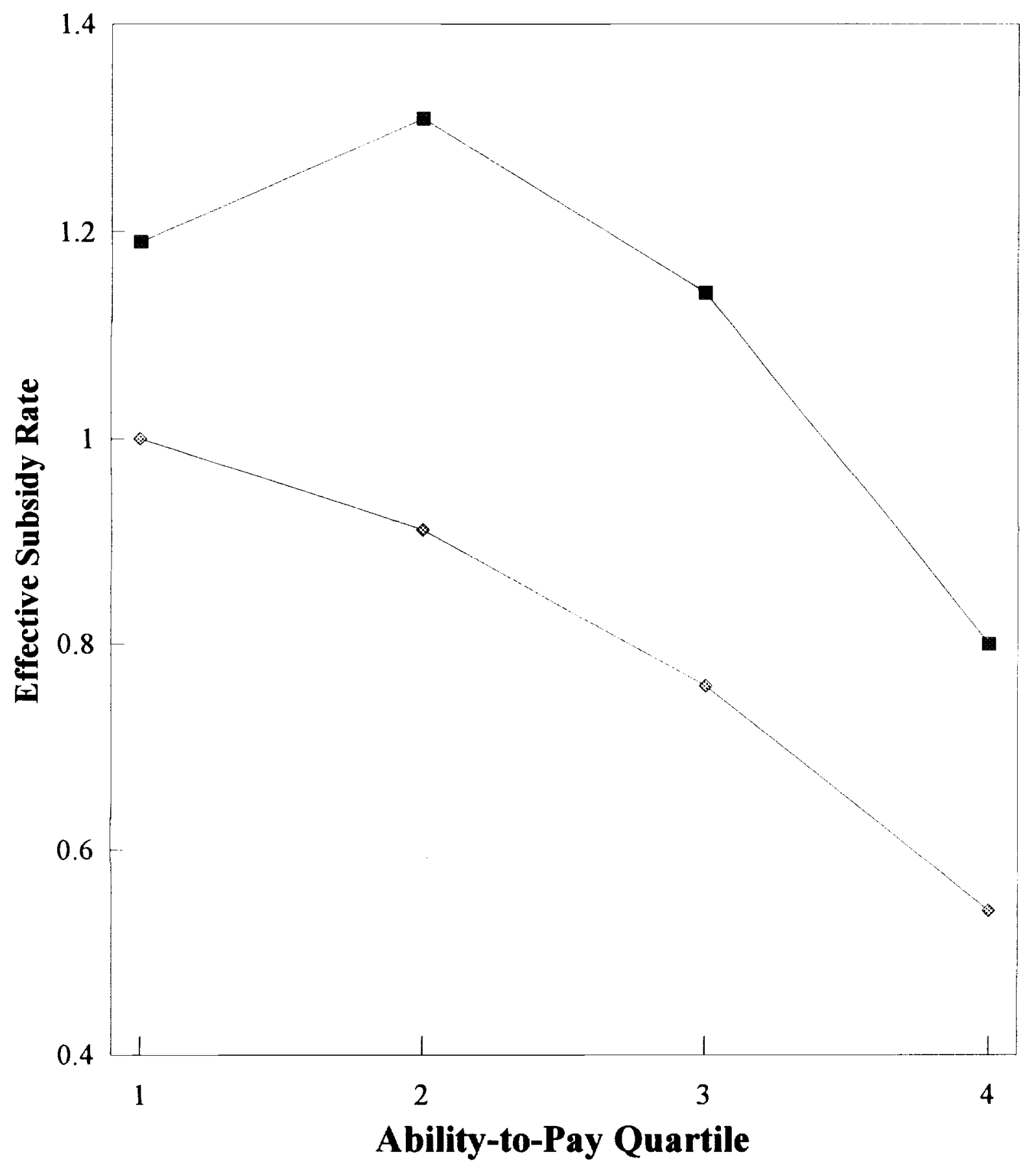

- Reported Income $\triangle$ Potential Income 